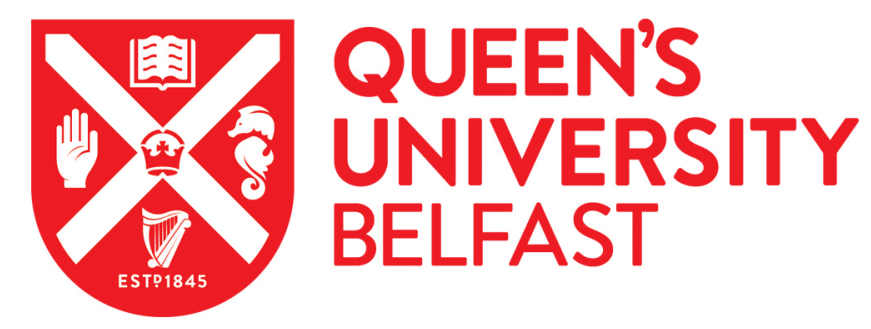

\title{
Radiological characterization of clay mixed red mud in particular as regards its leaching features
}

\author{
Hegedus, M., Sas, Z., Tóth-Bodrogi, E., Szántó, T., Somlai, J., \& Kovács, T. (2016). Radiological \\ characterization of clay mixed red mud in particular as regards its leaching features. Journal of Environmental \\ Radioactivity, 162-163, 1-7. https://doi.org/10.1016/j.jenvrad.2016.05.002
}

Published in:

Journal of Environmental Radioactivity

\section{Document Version:}

Peer reviewed version

Queen's University Belfast - Research Portal:

Link to publication record in Queen's University Belfast Research Portal

Publisher rights

(c) 2016 Elsevier Ltd. This manuscript version is made available under the CC-BY-NC-ND 4.0 license http://creativecommons.org/licenses/bync-nd/4.0/which permits distribution and reproduction for non-commercial purposes, provided the author and source are cited.

\section{General rights}

Copyright for the publications made accessible via the Queen's University Belfast Research Portal is retained by the author(s) and / or other copyright owners and it is a condition of accessing these publications that users recognise and abide by the legal requirements associated with these rights.

Take down policy

The Research Portal is Queen's institutional repository that provides access to Queen's research output. Every effort has been made to ensure that content in the Research Portal does not infringe any person's rights, or applicable UK laws. If you discover content in the Research Portal that you believe breaches copyright or violates any law, please contact openaccess@qub.ac.uk. 
Radiological characterization of clay mixed red mud in particular as regards its leaching features

Names of the authors:

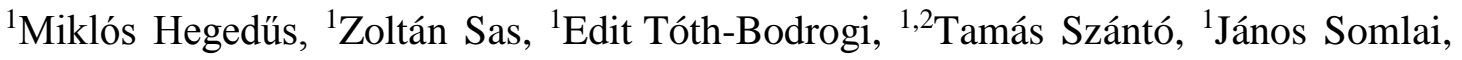
1,2Tibor Kovács

Affiliation(s) and address(es) of the author(s):

${ }^{1}$ Institute of Radiochemistry and Radioecology, University of Pannonia, 10 Egyetem str., H-8200, Veszprém, Hungary

${ }^{2}$ Social Organisation for Radioecological Cleanliness, 7/a József Attila str., H-8200, Veszprém, Hungary

*Corresponding author: Tibor Kovács, PhD; kt@almos.uni-pannon.hu

*Institute of Radiochemistry and Radioecology, University of Pannonia, P.O. Box 158, H-8201 Veszprém, Hungary 

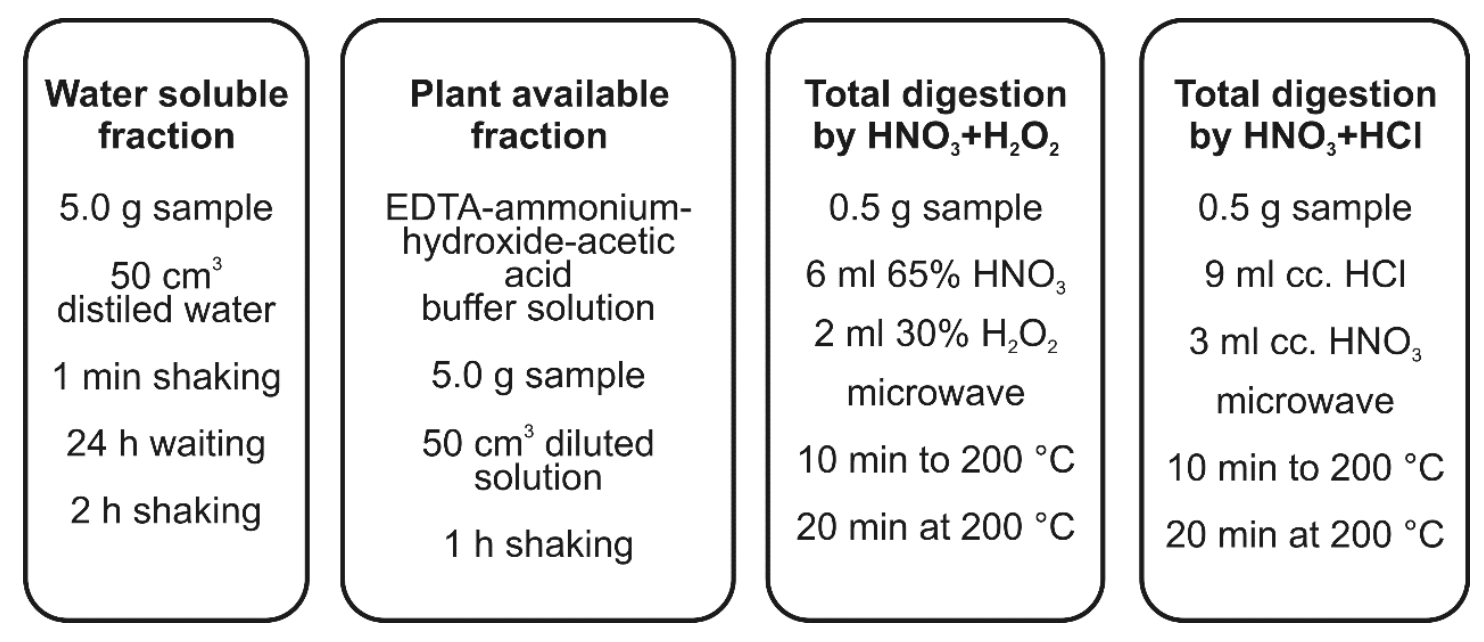

\section{Abstract}

The reuse of industrial by-products such as red mud is of great importance. In the case of the building material industry the reuse of red mud requires a cautious attitude, since the enhanced radionuclide content of red mud can have an effect on human health. The natural radionuclide content of red mud from the Ajka red mud reservoir and the clay sample from a Hungarian brick factory were determined by gamma spectrometry. It was found that maximum $27.8 \%$ red mud content can be added to fulfil the conditions of the EU-BSS. The effect of heat treatment was investigated on a red mud-clay mixture and it was found that in the case of radon and thoron exhalation the applied heat reduced remarkably the exhalation capacities. The leaching features of red mud and different mixtures were studied according to the MSZ-21470-50 Hungarian standard, the British CEN/TS 14429 standard and the Tessier sequential extraction method. The Tessier method and the MSZ-21470-50 standard are suitable for the characterisation of materials; however, they do not provide enough information for waste deposition purposes. To this end, we propose using the CEN/TS 14429 method, because it is easy to use, and gives detailed information about the material's behaviour under different $\mathrm{pH}$ conditions, however, further measurements are necessary.

\section{Keywords}

red mud; radon exhalation; by-product; leaching; building material industry; alpha spectrometry; gamma spectrometry 


\section{Introduction}

There is a good potential in the reuse of NORM (Naturally Occuring Radioactive Material) containing industrial by-products, for example, in the building industry. Several studies have dealt (Kovler et al., 2005, Somlai et al., 1997, 2008, Ducman et al., 2007, Szabo et al., 2013, Sas et al., 2015a) with finding environmentally friendly materials and methods, as well as low cost materials for building purposes.

The annual 90-120 million ton red mud production in the alumina industry, with the existing store of over 2.7 billion tons, offers a good choice due to its volume (Nutecelli

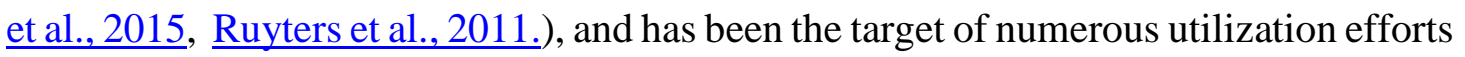
(Liu et al, 2012.) The traditional approach was wet or dry stockpiling or marine dumping, but due to the red mud's properties there is a risk of alkali, fluoride, heavy metal and other contaminations, causing severe environmental concerns. Better solutions are sought after; the most significant are the recovery of metals and rare earth elements, and use as construction material, with other possible alternatives utilising the high alkalinity or the heavy metal ion absorption capability (Qu et al, 2013, Liu et al, 2012.). Still the factors causing problems during deposition (alkalinity, heavy metal and other toxic compound content, radioactivity, etc.) remain.

Identification of environmental factors that pose a risk to human health along with understanding mechanisms leading to exposures have recently become important issues for scientists working with NORM. The production and design of new types of building materials based on NORM by-products is raising concerns among authorities, the public and scientists. It is incumbent on professional engineers and scientists to demonstrate that these materials do not pose significant risks to human health and the environment (WHO 2009, UNSCEAR 2008).

From a radiological point of view, three main problems can arise in the case of the NORM materials: the direct gamma dose rate, radon and thoron exhalation and leaching of radionuclides. The gamma dose rate has been seen asa health risk for a long time, and is covered by the RP 112 guideline.

The following activity concentration index (I) has been derived to identify whether a dose criterion is met: 


$$
I=\frac{C_{R a-226}}{300 B q / k g}+\frac{C_{T h-232}}{200 B q / k g}+\frac{C_{K-40}}{3000 B q / k g}
$$

Where $\mathrm{C}_{\mathrm{Ra}-226}, \mathrm{C}_{\mathrm{Th}-232}, \mathrm{C}_{\mathrm{K}-40}$ are the Ra-226, Th-232 and K-40 activity concentrations in $\mathrm{Bq} / \mathrm{kg}$.

The activity concentration index value of 1.0 can be used as a conservative screening tool for identifying materials that during their use would cause doses exceeding the reference level laid down in Article 75(1) of the 2013/59/EURATOM council directive. The council directive allows the dilution and mixing of construction materials as long as the final building product itself (the bricks) is below the activity concentration index value of 1.0 .

The radon isotopes are the major contributors to the ionizing radiation dose received by most of the population. The inhaled radon (Rn-222), thoron (Rn-220) and their progenies augment the risk of the evolution of pulmonary cancer (WHO 2009). Radon isotopes have a significant contribution to the natural background radiation of humans, the inhalation of Rn-222's short-lived progenies is responsible for about half of the total effective dose received by humans from all natural sources of ionizing radiation. The EU Member States are to establish national reference levels for indoor radon concentrations. The reference levels for the annual average activity concentration of the indoor air in workplaces (buildings, underground workplaces, e.g. mines, caves, etc.) and residential buildings must not exceed $300 \mathrm{~Bq} \mathrm{~m} \mathrm{~m}^{-3}$. (Article 75(1) of 2013/59/EURATOM).

Altough the main source of indoor radon is the soil, the radon exhalation of inbuilt materials should be kept as low as possible. For thoron the main source is the building material due to its short (55.6 s) half-life. In the case of elevated thoron exhalation the exposure to thoron may be even higher than the exposure to radon (Yonehara et al., 2005).

To ensure safe inbuilt building materials the exhalation of both isotopes should be reduced during production processes. If the thickness of the investigated sample is remarkably smaller than the diffusion length of radon or thoron all the emanated radon and thoron has a chance of being exhaled, i.e. the amount of the sample determines the exhalation rate, which can be related to unit mass. In the case of thoron a former survey 
performed by Csige et al., 2013 proved that in the case of adobe the optimal sample thickness is $5.0 \mathrm{~cm}$ to measure the thoron generation rate.

Owing to that fact, the determination of the massic exhalation rate can provide a great possibility to compare exhalation features of samples in granular form (Kovler et al., 2005, Mujahid et al,. 2005).

Leaching tests are a very important tool to assess the long-term environmental behaviour and environmental impact of various materials related to toxic compounds. In the EU, although there are encouraging tendencies for the standardisation of methods such as the LEAF protocols (Kosson et al., 2014), or the harmonisation of protocols for waste evaluation, there are still no commonly accepted methods for the evaluation of the leaching characteristics of NORM materials. The used methods vary greatly, ranging from sequential extraction procedures (Vandehove et al., 2014) to column tests (Nisti et al., 2015) and single step batch extractions (Lysandrou at al., 2007), both for scientific and regulatory purposes (Tiwari et al., 2015, Kosson et al., 2014).

\section{Measurements and methods}

\subsection{Sampling and sample preparation}

Red mud samples were collected from the Ajka red mud reservoir (1-2 m depth) and were homogenized; homogenized clay sample was gathered from a Hungarian brick factory. The samples were dried to constant mass at $105{ }^{\circ} \mathrm{C}$, crushed in a mortar and sieved under $0.63 \mathrm{~mm}$. Homogeneity was assured by representative sampling and homogenisation of the powdered samples by mixing. Before measurements the samples were stored for 30 days in $600 \mathrm{~cm}^{3}$ radon-tight aluminium Marinelli vessels to reach the radioactive equilibrium between Ra-226 and Rn-222, their short-lived progenies. For massic exhalation measurements spherical-shaped clay-based mixture samples were prepared containing $20 \%$ red mud content and with a $0.5 \mathrm{~cm}$ diameter. The samples were dried and heat-treated to follow the effect of different temperatures on radon and thoron exhalation features.

\subsection{Gamma spectrometry}

The Ra-226 activity concentration was obtained via the radon progenies Pb-214 (295 $\mathrm{keV}$ ) and Bi-214 (609 keV), the Th-232 content was determined from Ac-228 (911 keV) 
and Tl-208 (2614 keV) and the K-40 content was measured from the $1460 \mathrm{keV}$ gamma line (Shakhashiroa et al., 2012) by an ORTEC GMX40-76 HPGe detector. The sample measuring time was 80000 s. The system was calibrated with IAEA-326 soil reference material.

\subsection{Radon and thoron exhalation rates}

The radon and thoron exhalation rates of samples were measured using an accumulation chamber technique described in former studies (Sas et al., 2012, 2015b). To obtain the maximum thoron release rate of samples the prepared and treated spheres were put into an accumulation chamber with $5 \mathrm{~cm}$ thickness (Csige et al., 2013). After the accumulation time the radon and thoron content were measured together using an AlphaGUARD Pro radon monitor (SAPHYMO). After the sampling had finished the thoron decayed in the detector chamber and only the radon was inside. The AlphaGUARD radon monitor is a PIC (Pulse Ionization Chamber) detector, which cannot distinguish between radon and thoron. This is the reason why the thoron concentration was obtained from the measured activity concentration difference. To obtain accurate thoron concentration measurements using an AlphaGUARD, a RAD7 type radon-thoron monitor (Durridge Co.) was used as a reference instrument.

\subsection{Leachability experiments}

The leaching features of red mud, clay and clay-mixed red mud were investigated using different leaching methods, the MSZ-21470-50:2006 Hungarian standard, the British CEN/TS 14429 standard and Tessier sequential extraction. The MSZ-21470-50 Hungarian standard has been selected because it's the most common test used in environmental protection for heavy metals in soil in Hungary. It contains 4 different batch extractions, including aqua regia and $\mathrm{HNO}_{3}+\mathrm{H}_{2} \mathrm{O}_{2}$, which are necessary to give the total content of the material as a base of reference. It should be kept in mind while these methods are called 'total digestion methods', true total digestion would require additional reagents, such as $\mathrm{HF}$ and $\mathrm{HClO}_{4}$. The distilled water test is for simulating availability to rainwater (very similar to other common standards such as EN 12457-2, DIN 38414-S4 or the ASTM D 3987-85), while the Lakanen-Erviö solution is used for the estimation of availability for plants. Further advantages of the MSZ-21470-50 are: 
small amount of sample is necessary, it takes little time, and has a low cost compared to other methods. It has to be noted that while batch tests are very good for regulatory purposes and give indication about future leaching behaviour, the actual leaching on the field will differ according to the actual conditions (Ruyters et al., 2011.). The CEN/TS 14429 standard is a commonly used method in waste disposal for the determination of waste behaviour under different $\mathrm{pH}$ conditions, furthermore it is closely related to other widely used methods such as US EPA method 1313 and CEN/TS14497. The pH dependence of leaching behaviour is very important in case of co-deposition with other wastes, and in methods when red mud is used to neutralise acidic compounds, its $\mathrm{pH}$ is adjusted to fit in with existing building material production or other reasons (Liu et al, 2012.). The Tessier extraction is a well-known speciation method. It gives information about to what species are the leached compounds bound to and under what conditions do they become available. All leachates were analysed by alpha-spectrometry after separation by extraction chromatography using UTEVA resin and electro-deposition of U species (Jobbágy et al., 2010). While other relevant radionuclides are present in red mud, such as Ra-226, Th-232, Po-210, Pb-210 the U-238 and U-234 has been selected to try out and evaluate the leaching tests.

\subsubsection{MSZ-21470-50:2006 Hungarian standard}

MSZ-21470-50:2006 is the Hungarian standard (Hungarian Standards Institution) for the measurement of toxic elements, heavy metals and Chrome(VI) in soil for environmental protection purposes. It consists of 4 separate single-step batch processes (Figure 1):

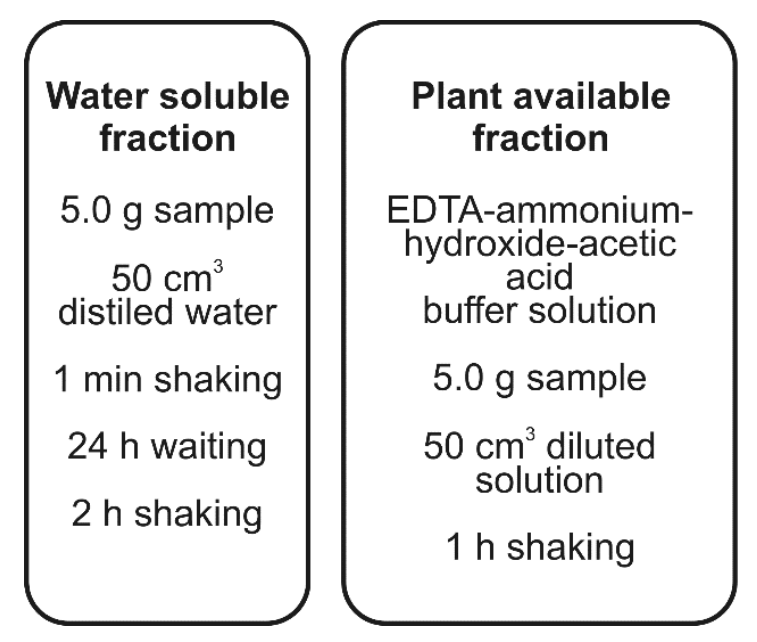

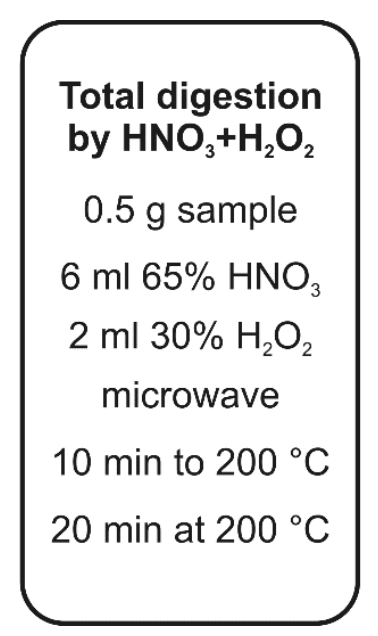

Total digestion by $\mathrm{HNO}_{3}+\mathrm{HCl}$

$0.5 \mathrm{~g}$ sample $9 \mathrm{ml} \mathrm{cc} . \mathrm{HCl}$ $3 \mathrm{ml} \mathrm{cc} . \mathrm{HNO}_{3}$ microwave $10 \mathrm{~min}$ to $200^{\circ} \mathrm{C}$ $20 \mathrm{~min}$ at $200^{\circ} \mathrm{C}$ 
Figure 1: Flowchart of MSZ-21470-50

1. Extraction with distilled water

This step is for the determination of the rainwater available fraction.

$50 \mathrm{~cm}^{3}$ of distilled water was added to a $5.0 \pm 0.01 \mathrm{~g}$ sample, the vessel was shaken vigorously for 1 minute, then was left to rest for 24 hours at room temperature. After the resting period the sample was shaken for 2 hours, then it was filtered using a 0.45 $\mu \mathrm{m}$ membrane filter, the U-232 tracer was added, and the solution was taken for radiochemical separation and measurement.

\section{Extraction with Lakanen-Erviö solution}

This step is for the determination of the dilute puffer $\left(0.5 \mathrm{~mol} / \mathrm{dm}^{3}\right.$ ammonium acetate $+0.5 \mathrm{~mol} / \mathrm{dm}^{3}$ acetic acid $+0.02 \mathrm{~mol} / \mathrm{dm}^{3}$ EDTA) available fraction. This is considered to indicate the availability for uptake by plants. As it has been noted before the actual uptake by a given plant greatly depends on the local conditions (Ruyters et al., 2011.), however, because of the simplicity and rapid conduct of the Lakanen-Erviö extraction, it is widely used by the Hungarian authorities.

The puffer solution was prepared in a $1000 \mathrm{~cm}^{3}$ volumetric flask. First $175 \mathrm{~cm}^{3}$ of concentrated ammonium hydroxide was added to $29.25 \mathrm{~g}$ of EDTA, then $400 \mathrm{~cm}^{3}$ of distilled water was added after dissolution. After that, $285 \mathrm{~cm}^{3}$ of $96 \mathrm{~m} / \mathrm{m} \%$ acetic acid and roughly $400 \mathrm{~cm}^{3}$ of distilled water was added. The $\mathrm{pH}$ was set to $4.65 \pm 0.03$ by 3 $\mathrm{mol} / \mathrm{dm}^{3}$ acetic acid or ammonium hydroxide, then distilled water was added to reach the $1000 \mathrm{~cm}^{3}$ mark. The dilute puffer solution was made by diluting the concentrated solution 1 to 5 , and adjusting the $\mathrm{pH}$ to $4.65 \pm 0.03$ if necessary.

The extraction was made by adding $50 \mathrm{~cm}^{3}$ of diluted puffer solution to $5.0 \pm 0.01 \mathrm{~g}$ of dry sample, shaking it for one hour, then filtering it using a $0.45 \mu \mathrm{m}$ membrane filter, the U-232 tracer was added, and the solution was taken for radiochemical separation and measurement. Originally the first $10 \mathrm{~cm}^{3}$ of liquid was to be discarded, but in our case, this wasn't necessary, because of the measurement method.

3. Digestion by $\mathrm{HNO}_{3}+\mathrm{H}_{2} \mathrm{O}_{2}$ 
The MSZ-21470-50 offers the choice between traditional chemical digestion and microwave digestion. The procedure was as follows: $0.5 \mathrm{~g}$ of sample was measured in the vessel of the microwave digester, then $6 \mathrm{~cm}^{3}$ of $65 \% \mathrm{HNO}_{3}, 2 \mathrm{~cm}^{3}$ of $\mathrm{H}_{2} \mathrm{O}_{2}$ and the U-232 tracer were added. The vessel was closed, and the microwave program was set to reach $200{ }^{\circ} \mathrm{C}$ in 10 minutes, and stay at $200{ }^{\circ} \mathrm{C}$ for 20 minutes. After the vessel had cooled down, the solution was filtered, and taken for radiochemical separation and measurement.

\section{Total digestion by $\mathrm{HNO}_{3}+\mathrm{HCl}$}

The MSZ-21470-50 offers the choice between traditional chemical digestion and microwave digestion. The procedure was as follows: $0.5 \mathrm{~g}$ of sample was measured in the vessel of the microwave digester, then $9 \mathrm{~cm}^{3}$ of $\mathrm{cc}$. $\mathrm{HCl}, 3 \mathrm{~cm}^{3}$ of $\mathrm{HNO}_{3}$ and the $\mathrm{U}$ 232 tracer were added. The vessel was closed, and the microwave program was set to reach $200{ }^{\circ} \mathrm{C}$ in 10 minutes, and stay at $200{ }^{\circ} \mathrm{C}$ for 15 minutes. After the vessel had cooled down, the solution was filtered, and taken for radiochemical separation and measurement.

\subsubsection{Tessier sequential extraction}

The Tessier sequential extraction is a 5-step process (Figure 2.), originally for the speciation of heavy metals (Tessier et al., 1979). The referred method describes the procedure for $1 \mathrm{~g}$, but for the measurement of natural radionuclides $5 \mathrm{~g}$ was necessary because of the small concentrations.
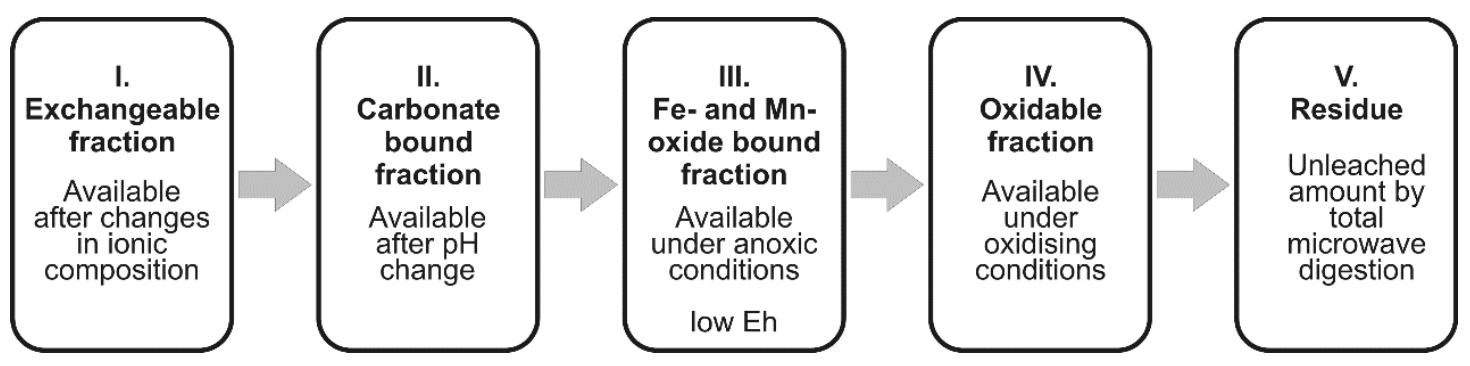

Figure 2: Flowchart of the Tessier 5-step sequential extraction

1. Exchangeable fraction, susceptible to changes in water ionic composition. $40 \mathrm{~cm}^{3}$ of $1 \mathrm{M} \mathrm{MgCl}_{2}$ adjusted to $\mathrm{pH} \mathrm{7,1} \mathrm{h} \mathrm{constant} \mathrm{agitation}$

2. Carbonate bound fraction becomes available with the changing of $\mathrm{pH}$. 
$40 \mathrm{~cm}^{3}$ of $1 \mathrm{M} \mathrm{NaOAc}$, adjusted to $\mathrm{pH} 5$ with acetic acid, 5 h constant agitation.

3. Iron and manganese oxide bound fraction, thermodynamically unstable in anoxic conditions (low Eh)

$80 \mathrm{~cm}^{3}$ of $0.04 \mathrm{M} \mathrm{NH}_{2} \mathrm{OH}^{*} \mathrm{HCl}$ in $25 \%$ acetic acid, $93 \pm 3{ }^{\circ} \mathrm{C}, 6 \mathrm{~h}$ with occasional agitation

4. Oxidizable fraction becomes available under oxidizing conditions.

$15 \mathrm{~cm}^{3}$ of $0.02 \mathrm{M} \mathrm{HNO}_{3}$ and $25 \mathrm{~cm}^{3}$ of $30 \% \mathrm{H}_{2} \mathrm{O}_{2}$ adjusted to $\mathrm{pH} 2$ with $\mathrm{HNO}_{3}$, $85 \pm 2{ }^{\circ} \mathrm{C}, 2 \mathrm{~h}, 15 \mathrm{~cm}^{3}$ of $30 \% \mathrm{H}_{2} \mathrm{O}_{2}$ adjusted to $\mathrm{pH} 2$ with $\mathrm{HNO}_{3}, 85 \pm 2{ }^{\circ} \mathrm{C}$, 2h, wait for it to cool, $15 \mathrm{~cm}^{3}$ of $3.2 \mathrm{M} \mathrm{NH}_{4} \mathrm{OAc}$ in $20 \% \mathrm{HNO}_{3}$ adjusted to $100 \mathrm{ml}$ with distilled water, 30 minute agitation

5. Residue, considered naturally not available over a reasonable timescale. Total microwave digestion 0.5 g sample $9 \mathrm{~cm}^{3}$ of cc. $\mathrm{HCl}, 3 \mathrm{~cm}^{3}$ of cc. $\mathrm{HNO}_{3}$, microwave $10 \mathrm{~min}$ to $200{ }^{\circ} \mathrm{C}, 15 \mathrm{~min}$ at $200{ }^{\circ} \mathrm{C}$

\subsubsection{British CEN/TS 14429 standard}

The British $\underline{\text { CEN/TS } 14429}$ is a standard used for waste evaluation under different $\mathrm{pH}$ conditions. The test is composed of at least 8 parallel batch extractions, with initial acid and base addition covering the range of $\mathrm{pH} 4$ to 12 .

The $\mathrm{HNO}_{3}$ or $\mathrm{NaOH}$ was added in three steps to $15 \mathrm{~g}$ of the sample with a liquid to solid ratio of 10, at the beginning, after 30 minutes, and after 2 hours. The amount of acid and base added must be chosen in a way that at the end of the procedure the range of $\mathrm{pH} 4$ to 12 is covered with no more than $1.5 \mathrm{pH}$ difference between the subsequent batches. In addition, the sample was tested at its natural $\mathrm{pH}$. The vessels were shaken for 48 hours at $20{ }^{\circ} \mathrm{C}$. The $\mathrm{pH}$ of each solution was measured after 4, 44 and 48 hours. If the $\mathrm{pH}$ change between the 44 and 48 hour values was no greater than 0.3 , the decision threshold for equilibrium condition had been reached. The leachate was separated from the solid phase and taken for radiochemical separation and measurement.

\section{Results and Discussion}

\section{Determination of the gamma dose surplus (I-index)}

The natural radionuclide content of the deposited red mud varied significantly, which requires frequent sampling and homogenizing before reuse. The Ra-226 content of 
surveyed red mud samples was $182 \pm 15$ Bq/kg, $245 \pm 29$ Bq/kg for Th-232, and $284 \pm$ $29 \mathrm{~Bq} / \mathrm{kg}$ for K-40. Compared to other bauxite residues these values exhibit lower than average (Ra-226: 337 Bq/kg, Th-232: 480 Bq/kg, K-40: 205 Bq/kg) activity concentrations for Ra-226 and Th-232 (Nutecelli et al., 2015). Only the K-40 activity concentration of red mud was significantly higher than the world average of the soils reported in UNSCEAR2008 Annex B (Ra-226: 32 Bq/kg, Th-232: 45 Bq/kg, K-40: 412 $\mathrm{Bq} / \mathrm{kg}$ ) and Radiation Protection 112 (Ra-226: 40 Bq/kg, Th-232: 40 Bq/kg, K-40: $400 \mathrm{~Bq} / \mathrm{kg}$ ). The investigated clay sample exhibited $40 \pm 8$ Bq/kg Ra-226, $40 \pm 11 \mathrm{~Bq} / \mathrm{kg}$ Th-232 and $907 \pm 40 \mathrm{~Bq} / \mathrm{kg}$ K-40 content. The calculated maximum allowable mixing ratio was $27.8 \%$ in the case of used compounds. In the case of a former study 27 clayfield of the most important Hungarian brick factories were surveyed in addition to 68 red mud samples from Ajka reservoirs (Sas et al 2012). Due to the inhomogeneity of the source materials $\sim 20 \%$ red mud content can be safely added to those clays to stay below the 1.0 I-index value in every case. This is the reason why a maximum of $20 \%$ red mud content was used for the experiments.

\section{Radon and thoron exhalation}

The exhalation rate dependency was plotted as a function of the applied heat-treatment in the cases of red mud and the clay-red mud mixture (Figure 3). It was found that the heat-treatment has a beneficial effect on radon and also on thoron exhalation characteristics of red mud and of the mixture as well. Above $800^{\circ} \mathrm{C}$ the measured exhalation rate was significantly lower than in the case of the non-treated materials. Owing to that fact the mixing of red mud with clays can be a solution to produce building materials with reduced radon exhalation features. As was expected the obtained radon and thoron exhalation characteristics were similar since the emanation phenomena of both isotopes are similar. 


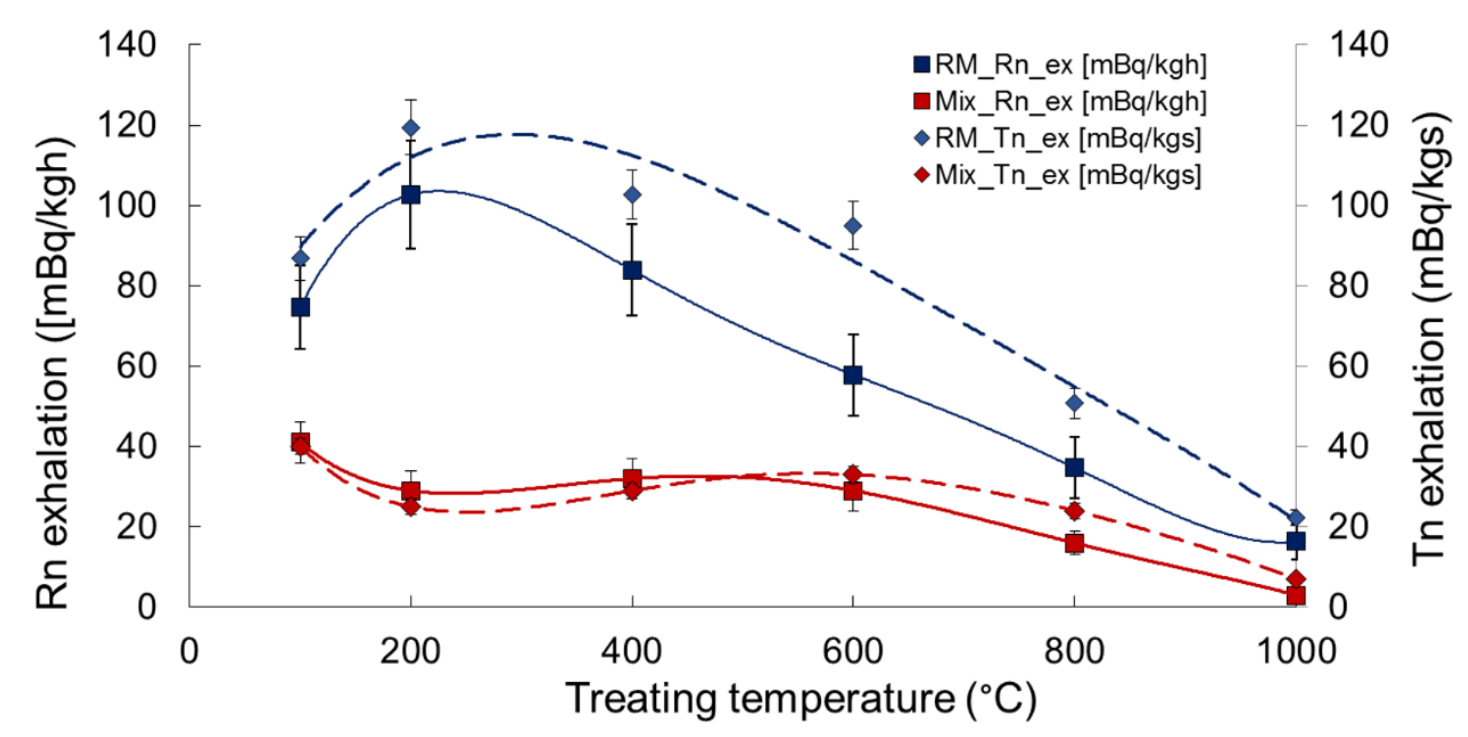

Figure 3: Effects of heat treatment on radon exhalation characteristics

The heat-treatment does not require any changes in e.g. brick production since the applied heat in the case of used kilns is between 800 and $1000^{\circ} \mathrm{C}$. In a previous study published by Sas et al., 2015b, it was found that a strong correlation can be observed between nanoporosity $(0-100 \mathrm{~nm})$ and emanation, which is the source of the exhaled radon. Owing to current results on related samples it can be stated that a similar tendency can be observed in the case of thoron exhalation, which means the heattreatment and resultant reduction of nanoporosity can be a good solution to produce building materials with low radon and thoron exhalation capacities.

\section{Leachability experiments}

The results of leachability experiments are presented in the figures below. Figure 4. and 5. present the results for red mud. For total microwave digestion by nitrohydrochloric acid $262 \pm 19$ Bq/kg U-238 (21.4 $\pm 1.6 \mathrm{mg}$ U-238/kg sample) was measured (100\%), while the leached amount was $~ 75 \%$ with $\mathrm{HNO}_{3}+\mathrm{H}_{2} \mathrm{O}_{2}$ digestion, 26 \% with Lakanen-Erviö solution, and $\sim 4.5 \%$ with distilled water; for Tessier: step I. 1 \%, step II. 1 \%, step III. 30 \%, step IV. 7\%, step V. 61\%. 


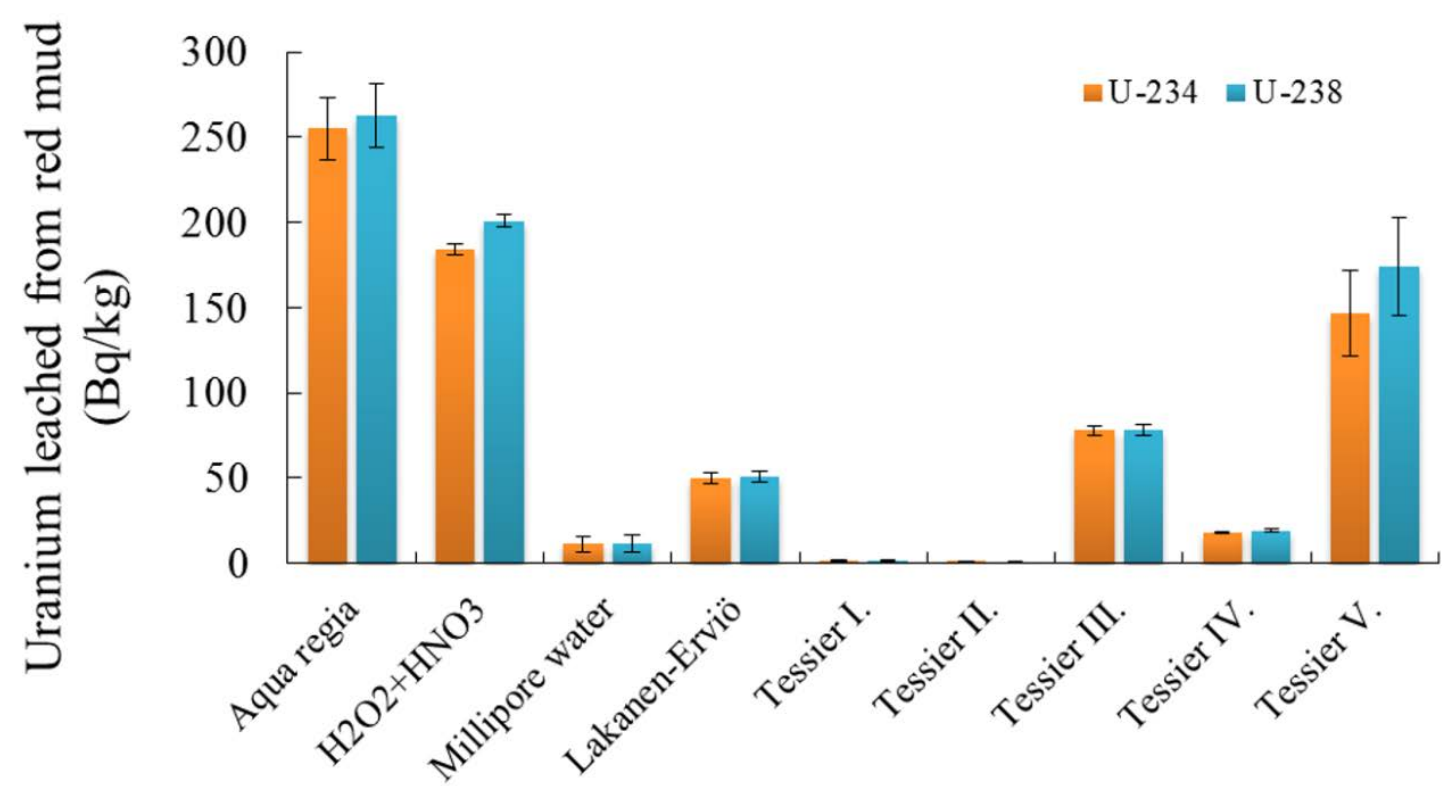

Figure 4: The measured activity concentrations of leaching tests performed on red mud

\section{Uranium leached from red mud under different} $\mathrm{pH}$ conditions

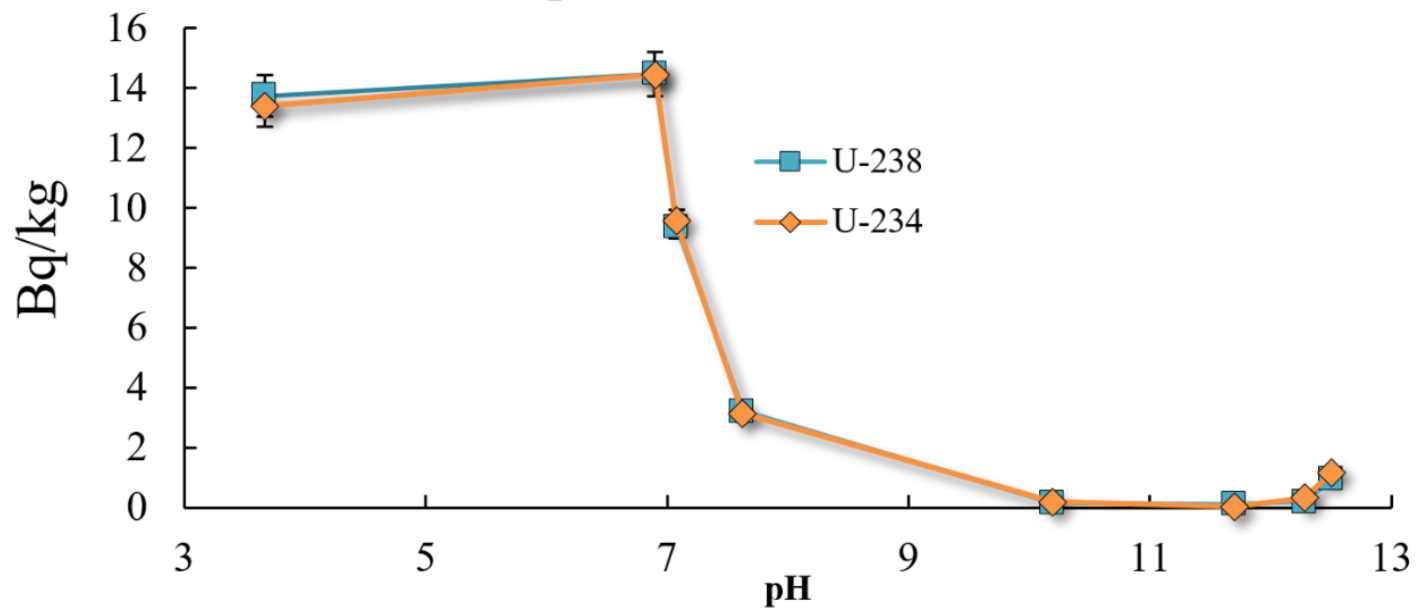

Figure 5. The measured activity concentrations of the CEN/TS 14428 experiments performed at various $\mathrm{pH}$ values on red mud

The results indicate that while the directly water-soluble fraction is relatively small, with the changing of $\mathrm{pH}$ or red-ox potential a considerable amount of the red mud's uranium content becomes available for leaching. In the case of red mud the Tessiermethod showed that the majority of the leachable uranium is bound to the iron- and manganese-oxide bound fractions. A small fraction of uranium is available under anoxic conditions. The Hungarian MSZ-21470-50 standard indicated that 26\% of the uranium 
content in red mud is available for plants, so it can get into the food chain. As noted before the actual uptake by a given species is greatly dependent on the actual conditions, batch laboratory tests only indicate the possible behaviour. The CEN/TS 14429 standard indicates that while very little U leaches from red mud under alkaline conditions, under acidic conditions $5.5 \%$ of the total $U$ content becomes available. Comparing the three methods it can be said that the parallel single step extractions were faster and simpler than the Tessier method, which is more detailed. The CEN/TS 14429 standard gives detailed information about the effects of $\mathrm{pH}$, but other factors are not considered. As for red mud the directly available to water fraction of uranium is relatively small, around $0,25 \mathrm{~Bq} / \mathrm{l} \mathrm{U}-238$ or $20 \mu \mathrm{g} \mathrm{U} / \mathrm{l}$ leachate, for drastic $\mathrm{pH}$ change these values would be around 1,4 Bq/l U-238 or $115 \mu \mathrm{g}$ U/l leachate, with changes of red-ox potential 7,86 Bq/l U-238 or $640 \mu \mathrm{g}$ U/l leachate becomes available. The Lakanen-Erviö solution had around 6,8 Bq/l U-238 or $556 \mu \mathrm{g}$ U/l leachate uranium content. Most of these values are well above the $30 \mu \mathrm{g} / 1 \mathrm{U}$ for drinking water suggested by the WHO Guideline for Drinking-water Quality and the US Safe Drinking Water Act, thus reinforcing the necessity of the safe separation of red mud depositories from aquifers.

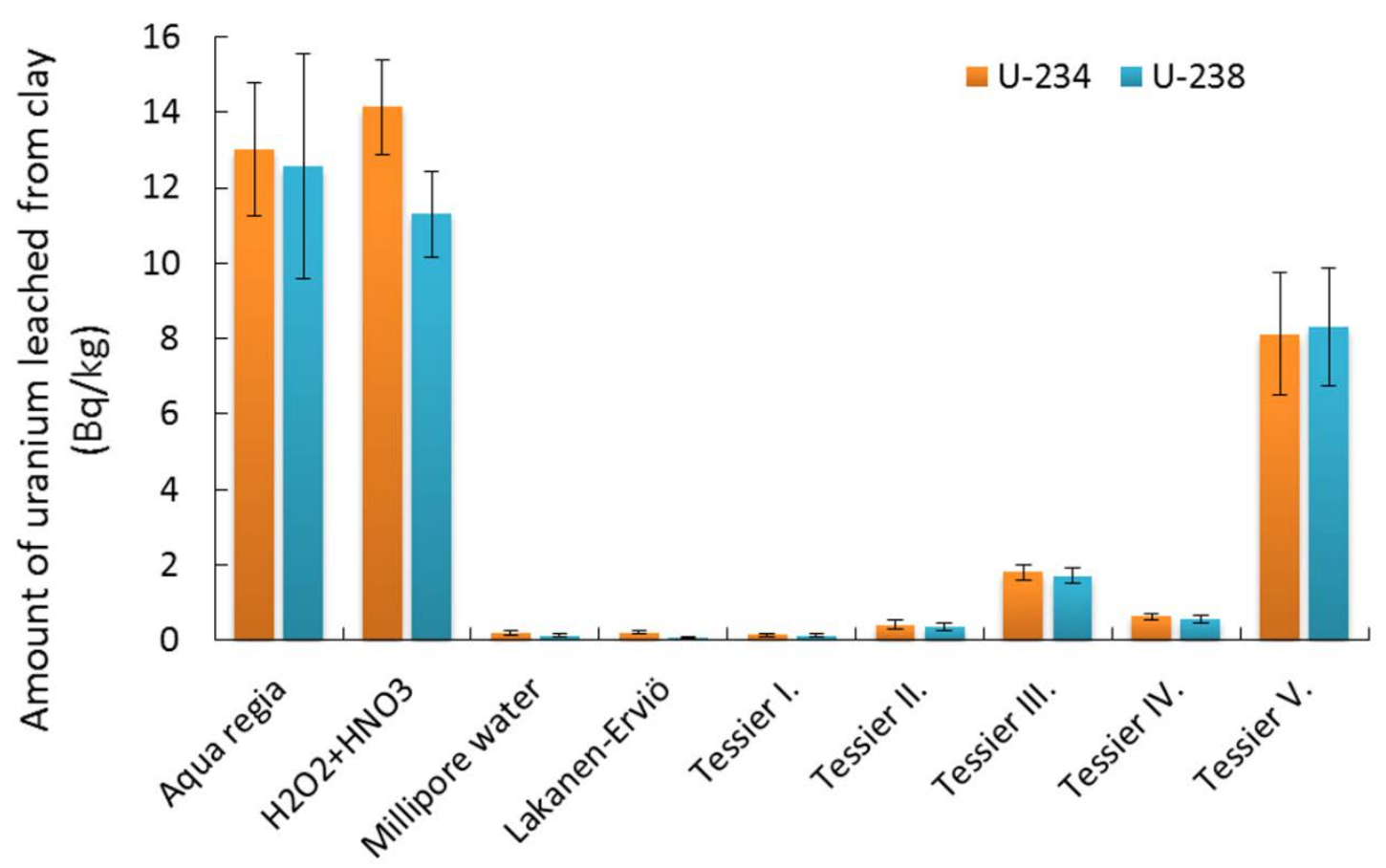

Figure 6: The measured activity concentrations of leaching tests performed on clay In the case of clay (Figure 6.) the measured activity concentrations $(11.9 \pm 2.8 \mathrm{~Bq} / \mathrm{kg})$ are well below those measured in the case of bauxite residue, and the ratios are also 
different. There is a small fraction of 3.4\% attached to the $\mathrm{pH}$-susceptible fraction, $15.8 \%$ is bound to the iron and manganese oxides, and $5.3 \%$ is bound to the oxidizable fraction, while $74.3 \%$ remains in the residue, considered unavailable under environmental conditions.

In the case of model bricks (Figure 7.) less uranium becomes available, compared to red mud. With increasing red mud content the oxidizable fraction becomes more pronounced, less uranium is available to changes in red-ox potential, and more leaches out under anoxic conditions.
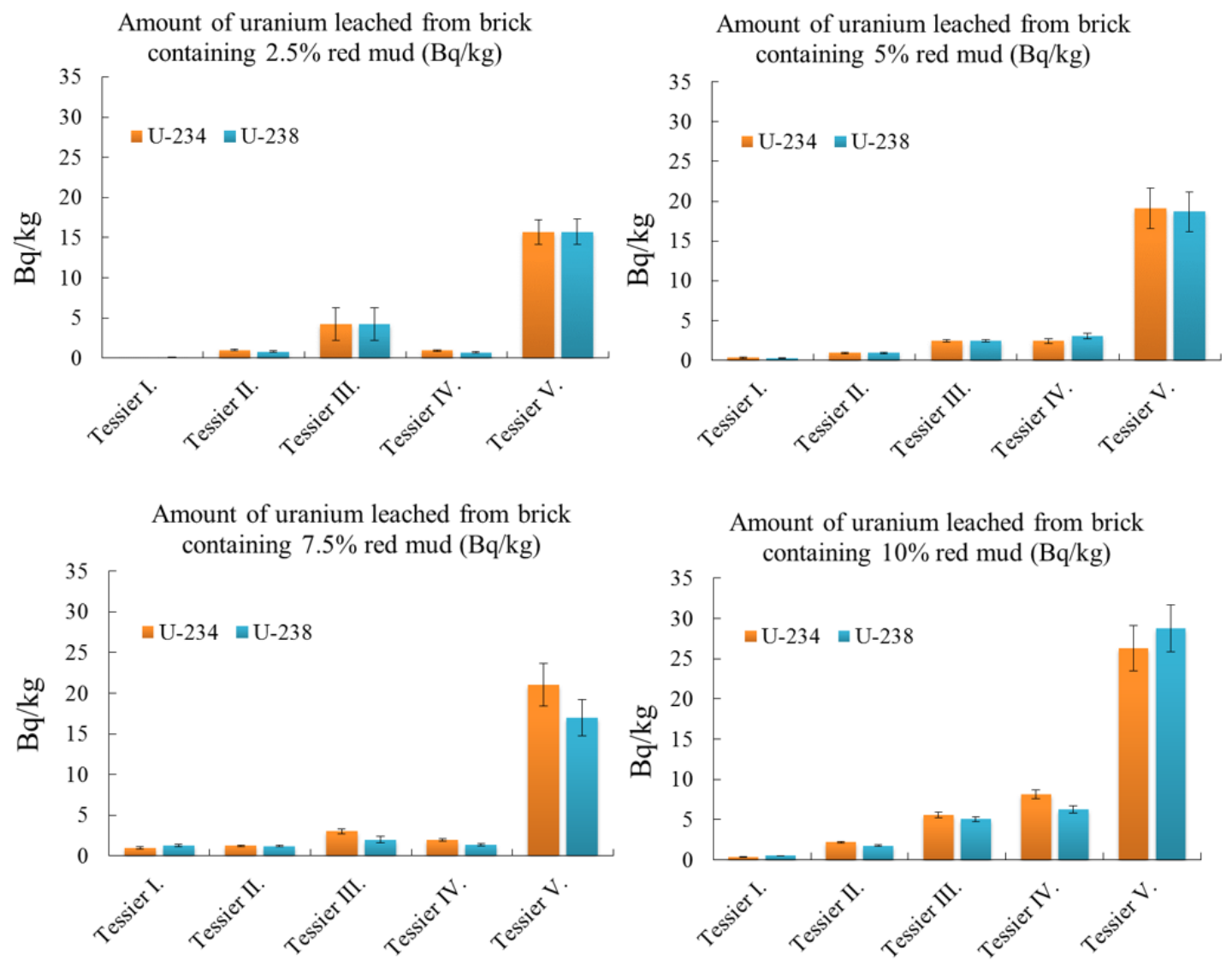

Figure 7: The measured activity concentrations of leaching tests performed on bricks with different red mud contents

With increasing red mud concentration in the mix a higher percentage of uranium becomes available, indicating a maximum for the brick's capability to retain uranium. While the firing process had a significant effect on the radon (Sas et al., 2015b) and thoron exhalation characteristics of the material, it had less effect on leaching 
characteristics, only around a 10\% decrease. This indicates that opposed to the Rnisotopes the release of $U$ is not closely connected to the nanoporosity.

\section{Conclusion}

- After heat treatment above $800^{\circ} \mathrm{C}$ both the measured radon and thoron exhalation rates were significantly lower than in the case of the non-treated materials. This means that the mixing of red mud with clays and utilization as bricks can be a solution to produce building materials with reduced exhalation features.

- As was expected the obtained radon and thoron exhalation characteristics were similar since the emanation phenomena of both isotopes are similar.

- The Tessier method and the MSZ-21470-50 standard are suitable for the characterization of materials; however, they do not provide enough information for waste disposal purposes. To this end, we propose using the CEN/TS 14429 method from the methods discussed in the article, because it is easy to use, and gives information of the material's behaviour under different $\mathrm{pH}$ conditions. However, further measurements are necessary, because waste disposal is a very complex matter and no single test can cover all necessary information. The CEN/TS 14429 method also has its limitations, but since it's already in use in waste disposal facilities the measurement of radionuclides can easily be included in the standard protocol.

\section{ACKNOWLEDGEMENTS}

This work was supported by European Union and the State of Hungary, and it was cofinanced by the European Social Fund in the framework of TÁMOP 4.2.4. A/2-11-12012-0001 'National Excellence Program'. The authors would like to acknowledge the networking support of the COST Action TU1301, www.norm4building.org.

\section{References}


Csige, I., Szabó, Zs., Szabó, Cs., 2013. Experimental technique to measure thoron generation rate of building material samples using RAD7 detector, Radiat. Meas., 59, 201-204. doi:10.1016/j.radmeas.2013.07.003

Council of the European Union, 2014. Council directive 2013/59/EURATOM, European Basic Safety Standards (BSS) for protection against ionising radiation OJ of EU, L 13/1, Brussels.

Ducman, V., Kopar, T., 2007. The influence of different waste additions to clay-product mixtures, Mater.Tech., 41, 289-293. http://mit.imt.si/Revija/izvodi/mit076/ducman.pdf

European Comission, 1999. Radiation Protection 112 - Radiological Protection Principles concerning the Natural Radioactivity of Building Materials, European Commission, Luxemburg.

Hungarian Standards Institution, 2006. MSZ 21470-50:2006: Environmental testing of soils. Determination of total and soluble toxic element, heavy metal and chromium(VI) content. MSZT, Budapest.

Jobbágy, V., Kávási, N., Somlai, J., Máté, B., Kovács, T., 2010. Radiochemical characterization of spring waters in Balaton Upland, Hungary, estimation of radiation dose to members of public. Microchem. J. 94, 159-165. doi:10.1016/j.microc.2009.10.015

Kosson, D.S., van der Sloot, H.A., Garrabrants, A.C., Seignette, P.F.A.B., 2014. Leaching Test Relationships, Laboratory-to-Field Comparisons and Recommendations for Leaching Evaluation using the Leaching Environmental Assessment Framework. US EPA EPA-600/R-14/061

http://www.vanderbilt.edu/leaching/wordpress/wp-content/uploads/600r14061-Lab-toField-LEAF1.pdf 
Kovler, K., Perevalov, A., Steiner, V., Metzger, L.A., 2005. Radon exhalation of cementitious materials made with coal fly ash: Part 1: scientific background and testing of the cement and fly ash emanation. J. Environ. Radioactiv. 82, 321-34. doi:10.1016/j.jenvrad.2005.02.004

Liu, D.-Y., Wu, C.-S., 2012. Stockpiling and Comprehensive Utilization of Red Mud Research Progress. Materials, 5, 1232-1246. doi:10.3390/ma5071232

Lysandrou, M., Pashalidis, I., 2008. Uranium chemistry in stack solutions and leachates of phosphogypsum disposed at a coastal area in Cyprus. J. Environ. Radioactiv., 99, 359-366. doi:10.1016/j.jenvrad.2007.08.005

Mujahid, S.A., Hussain, S., Dogar, A.H. and Karim, S. 2005. Determination of porosity of different materials by radon diffusion. Radiat. Meas., 40, 106-109. doi:10.1016/j.radmeas.2005.04.006

Nisti, M.B., Saueia, C.R., Malheiro, L.H., Groppo, G.H., Mazzilli B.P., 2015. Lixiviation of natural radionuclides and heavy metals in tropical soils amended with phosphogypsum. J. Environ. Radioactiv., 144, 120-126. doi:10.1016/j.jenvrad.2015.03.013)

Nuccetelli, C., Pontikes, Y., Leonardi, F., Trevisi R., 2015. New perspectives and issues arising from the introduction of (NORM) residues in building materials: A critical assessment on the radiological behaviour, Constr. Build. Mater, 82, 323-331. doi: 10.1016/j.conbuildmat.2015.01.069

Qu, Y., Lian, B. 2013. Bioleaching of rare earth and radioactive elements from red mud using Penicillium tricolor RM-10. Bioresour Technol. 136, 16-23. doi:10.1016/j.biortech.2013.03.070

Ruyters, S., Mertens, J., Vassilieva, E., Dehandschutter, B., Poffijn, A., Smolders, E., 2011. The Red Mud Accident in Ajka (Hungary): Plant Toxicity and Trace Metal 
Bioavailability in Red Mud Contaminated Soil. Environ Sci Technol, 45, 1616-1622. doi: 10.1021/es104000m

Sas, Z., Somlai, J., Jonas, J., Szeiler, G., Kovacs, T., Gyongyosi, Cs., Sydo, T., 2012. Radiological survey of Hungarian clays; radon emanation and exhalation influential effect of sample and internal structure conditions. Rom. J. Phys 58, 243-250. http://www.nipne.ro/rjp/2013_58_Suppl/0243_0250.pdf

Sas, Z., Somlai, J., Szeiler, G., Kovacs, T., 2015a. Usability of clay mixed red mud in Hungarian building material production industry. J. Radioanal. Nucl. Chem., 306, 271275. doi:10.1007/s10967-015-3966-Z

Sas, Z., Szántó, J., Kovács, J., Somlai, J., Kovács, T., 2015b. Influencing effect of heattreatment on radon emanation and exhalation characteristic of red mud. J. Environ. Radioactiv. 148, 27-32. doi:10.1016/j.jenvrad.2015.06.002

Shakhashiroa, A., Tarjanb, S., Ceccatellia, A., Kis-Benedeka, G., Bettia, M., 2012, IAEA-447: A new certified reference material for environmental radioactivity measurements. Appl. Radiat. Isot., 70, 1632-1643. doi:10.1016/j.apradiso.2012.03.024

Somlai, J., Németh, Cs., Lendvai, Z., Bodnár, R., 1997. Dose contribution from school buildings containing coal slag insulation with elevated concentrations of natural radionuclides. J. Radioanal. Nucl. Chem., 218, 61-63. doi:10.1007/BF02033974

Somlai, J., Jobbagy, V., Kovacs, J., Tarjan, S., Kovacs, T., 2008. Radiological aspects of the usability of red mud as building material additive. J. Haz. Mat., 150,541-545. doi:10.1016/j.jhazmat.2007.05.004

Szabó, Zs., Völgyesi, P., Nagy, H.É., Szabó, Cs., Kis, Z., Csorba, O., 2013. Radioactivity of natural and artificial building materials - a comparative study. J. Environ. Radioactiv., 118, 64-74. doi:10.1016/j.jenvrad.2012.11.008 
Tessier, A., Campbell, P. G. C., Bisson, M., 1979. Sequential extraction procedure for the speciation of particulate trace metals. Anal. Chem., 51, 844-851. doi:10.1021/ac50043a017

The British Sandard Institution, 2006. DD CEN/TS 14429:2005 Characterization of waste. Leaching behaviour tests. Influence of $\mathrm{pH}$ on leaching with initial acid/base addition, The British Standard Institution, London.

Tiwari, M.K., Bajpai, S., Dewangan, U.K., Tamrakar R. K., 2015. Suitability of leaching test methods for fly ash and slag: A review. J. Radiat. Res. Appl. Sci., 8, 523537. doi:10.1016/j.jrras.2015.06.003

United Nations Scientific Committee on the effects of Atomic Radiation, 2010. Sources and effects of ionizing radiation, UNSCEAR 2008 Report to the General Assembly with Scientific Annexes, United Nations, Vienna.

Vandenhove, H., Vanhoudta, N., Duquène, L., Antunes, K., Wannijn, J., 2014. Comparison of two sequential extraction procedures for uranium fractionation in $\begin{array}{lllll}\text { contaminated } & \text { soils. } & \text { J. } & \text { Environ. } & \text { Radioactiv., }\end{array}$ doi:10.1016/j.jenvrad.2014.05.024

WHO, 2009. WHO Handbook on Indoor Radon: a public health perspective. World Health Organization, Geneva.

Yonehara, H., Tokonami, S., Zhuo, W., Ishikawa, T., Fukutsu, K.., Yamada, Y., 2005. Thoron in the living environments of Japan. Proceedings of the 6th International Conference on High Levels of Natural Radiation and Radon Areas, Int. Congr. Ser., 1276, 58-61. doi:10.1016/j.ics.2004.10.014

\section{List of Figures}

Figure 1: Flowchart of MSZ-21470-50

Figure 2: Flowchart of the Tessier 5-step sequential extraction 
Figure 3: Effects of heat treatment on radon exhalation characteristics

Figure 4: The measured activity concentrations of leaching tests performed on red mud Figure 5. The measured activity concentrations of leaching tests performed at various $\mathrm{pH}$ values on red mud

Figure 6: The measured activity concentrations of leaching tests performed on clay

Figure 7: The measured activity concentrations of leaching tests performed on bricks with different red mud contents 